CZASOPISMO INŻYNIERII LĄDOWEJ, ŚRODOWISKA I ARCHITEKTURY

JOURNAL OF CIVIL ENGINEERING, ENVIRONMENT AND ARCHITECTURE

JCEEA, t. XXXIV, z. 64 (3/II/17), lipiec-wrzesień 2017, s. 103-114, DOI:10.7862/rb.2017.157

Katarzyna JANICKA-ŚWIERGUŁA ${ }^{1}$

\title{
REWITALIZACJA DZIEDZICTWA ARCHITEKTONICZNEGO ŁODZI W RAMACH PROGRAMU ,MIA100 KAMIENIC”
}

\begin{abstract}
Celem artykułu jest omówienie założeń programu remontowego realizowanego od 2011 roku dla nieruchomości gminnych zlokalizowanych w strefie wielkomiejskiej Łodzi. Wśród obiektów objętych projektem „Mia100 Kamienic” znajdują się budynki mieszkalne i użyteczności publicznej, przedszkola, schroniska młodzieżowe, a także galerie sztuki wpisane do Wojewódzkiego Rejestru Zabytków oraz Gminnej Ewidencji Zabytków. Autorka zwraca uwagę na aspekt odtworzenia historycznej tkanki miejskiej z przełomu XIX i XX wieku w ramach założeń programu, jak również na społeczną rolę przeprowadzonych prac rewitalizacyjnych i podejmuje próbę odpowiedzi na pytanie, czy tego typu działania są remedium na aktywizację pustoszejącego centrum miasta. Analizie porównawczej poddano wybrane łódzkie obiekty mieszkalne oraz użyteczności publicznej pochodzące z przełomu XIX i XX wieku, w których przeprowadzono gruntowne remonty i prace rewitalizacyjne. Oprócz inicjatyw restauracyjno-budowlanych autorka przybliża spektrum zadań towarzyszących programowi „Mia100 Kamienic” mających podłoże społeczno-socjologiczne. Ponadto konfrontuje zrealizowane prace $\mathrm{z}$ dokonaniami rewitalizacyjnymi Wrocławia, w którym przeprowadzono pierwowzór łódzkiego programu remontowego. Rozważania prowadzą do konkluzji, iż wykonane działania remontowe oprócz podniesienia wartości wizualnej miasta spotkały się z pozytywnym odbiorem społecznym. Program przyczynia się do stopniowego zasiedlenia odnowionych budynków, a Łódź, w odczuciu mieszkańców, przestaje być synonimem szarej, nierokującej na zmianę aglomeracji. Rozpoczyna erę miasta świadomego swego dziedzictwa, bogactwa architektonicznego, jak również drzemiącego w nim potencjału.
\end{abstract}

Słowa kluczowe: program remontowy, kamienica, restauracja, zabytek, strefa wielkomiejska

„Łódź rodziła się w przeszłości dwukrotnie. Po raz pierwszy w 1423 roku, kiedy otrzymała z nadania króla Władysława Jagiełły prawa miejskie. Po raz drugi w 1820 roku, kiedy decyzją władz Królestwa Polskiego została zaliczona

\footnotetext{
${ }^{1}$ Katarzyna Janicka-Świerguła, Politechnika Łódzka, Instytut Architektury i Urbanistyki, ul. Biegańskiego 46, 91-475 Łódź; tel.: 692433 820; e-mail: katarzyna.janicka@ p.lodz.pl
} 
do grona miast przeznaczonych do rozwoju przemysłu włókienniczego." [4, s. 8]. Od kilku lat możemy być świadkami jej kolejnego „odrodzenia” za sprawą programów rewitalizacyjnych. Dzięki nim odzyskuje dawny blask i ujawnia skrywane przez dziesięciolecia piękno swojego dziedzictwa. Szczęśliwie, mimo trwającej przez lata niechęci do „,szarej Łodzi”, zachowała architektoniczną tożsamość przypominającą o dawnych europejskich relacjach włókienniczego ośrodka, a także o wieloetnicznej społeczności, która przyczyniła się do jej rozkwitu ([6], s. 151).

W drugiej połowie XIX wieku Łódź była najszybciej rozwijającym się miastem na ziemiach polskich. W 1860 roku liczyła 32629 mieszkańców, a po kolejnych 24 latach 113146 osób [2, s. 310]. W ciągu niewielu dziesięcioleci rozwinęła się $\mathrm{W}$ industrialną metropolię budowaną, w sensie dosłownym i w przenośni, głównie przez Niemców, Polaków i Żydów. Wszyscy uczestniczyli w powstawaniu nowego ośrodka. Ostatecznie wytworzyła się wieloetniczna społeczność jednocześnie podzielona i różnorodna, ale poddająca się integracji [3, s. 8-9].

Najbardziej czytelnym śladem obecności w Łodzi mieszkańców zróżnicowanych religijnie i narodowościowo są zabytki architektury, które ukazują zmieniające się style, mody i tendencje docierające, niekiedy z pewnym opóźnieniem, $\mathrm{z}$ artystycznych ośrodków starego kontynentu [6, s. 132]. W latach dziewięćdziesiątych XIX wieku masowo budowano kamienice czynszowe, które wypełniały wolne przestrzenie miasta i wypierały wcześniejsze budownictwo drewniane. Miały zwykle wysokość czterech lub pięciu kondygnacji i posiadały jednotraktowe oficyny, rozbudowywane stopniowo w głąb działki. Przybierały różnorodne formy architektoniczne o charakterze wielkomiejskim, najczęściej oparte o bogaty kostium historyzujący. Nowym składnikiem założeń urbanistycznych stały się także rezydencje przemysłowców zlokalizowane w zwartej zabudowie, co doprowadziło do silnego zróżnicowania gabarytów, form i funkcji w obrębie kwartałów [2, s. 310-311].

Nadzwyczajny rozwój miasta został brutalnie zahamowany przez II wojnę światową. Lata 1939-1945, mimo iż nie przyniosły znaczących zniszczeń w tkance budowlanej Łodzi, to odcisnęły piętno na jej strukturze narodowej i zachowaniu ciągłości kulturowej. Jej dawni mieszkańcy na skutek represji zginęli lub rozproszyli się po świecie. Społeczność rdzennych łodzian uzupełnili nowi przybysze, etnicznie jednolici, ale wywodzący się z różnych zakątków Polski. Sprowokowało to kolejne zmiany - ważne niegdyś miejsca i budowle stały się obojętne, a nazwiska twórców wielkoprzemysłowej Łodzi przestały cokolwiek znaczyć dla nowych pokoleń [3, s. 8-9]. Władze PRL wprowadziły publiczną gospodarkę lokalami przyczyniając się do postępującej materialnej degradacji kamienic. Deficyt mieszkań wymógł umieszczanie w dużych lokalach kilka obcych sobie rodzin tworząc wymuszone wspólnoty. Rozwój budownictwa spółdzielczego oferującego mniejsze mieszkania, ale wyposażone we wszystkie media spowodował stopniowe opuszczanie Śródmieścia przez lepiej 
sytuowanych łodzian. Władze kwaterunkowe traktowały pozostawione lokale w kamienicach jako mieszkania socjalne wprowadzając do nich lokatorów niewypłacalnych i często zdegradowanych społecznie. Niestety przyczyniło się to do powstania w centrum stref biedy, a nieremontowane obiekty zatracały stopniowo swoje walory użytkowe i estetyczne [5 s. 44].

Jeszcze do lat sześćdziesiątych XX wieku Łódź stanowiła w odczuciu opinii publicznej przykład brzydoty i chaosu przestrzennego. Tylko nieliczni badacze wskazywali na wartości historyczne i estetyczne budynków oraz elementów rozplanowania. W 1957 roku w rejestrze zabytków znajdowało się zaledwie 14 obiektów, z reguły wzniesionych przed rokiem 1850. Dopiero lata siedemdziesiąte przyniosły z inicjatywy Konserwatora Zabytków m. Łodzi opracowanie studium historyczno - urbanistycznego miasta określającego postulaty konserwatorskie do miejscowego planu ogólnego zagospodarowania oraz nowy spis zabytków nieruchomych, obejmujący 230 pozycji. Rozpoczęto także szczegółowe badania konserwatorskie śródmieścia, które miały na celu zgromadzenie informacji niezbędnych do określenia warunków rewaloryzacji analizowanego obszaru i wypracowania metod badawczych służących do rozpoznania cech i wartości XIX - wiecznych struktur. W wyniku analiz wykazano, iż w Łodzi wykształcił się typ zabudowy nie mający ścisłych odpowiedników w innych miastach Polski, a jego najbardziej charakterystycznymi obiektami okazały się wielkomiejskie kamienice czynszowe. Ponadto określono i zlokalizowano różnorodne zjawiska o cechach wartości kulturowych charakterystycznych dla przestrzennej specyfiki miasta, co miało pomóc $\mathrm{w}$ ich właściwym wyeksponowaniu w procesie rewaloryzacji śródmieścia [2, s. 311-313].

Niestety przez kolejne lata stan znacznej części tkanki zabytkowej stopniowo się pogarszał, mimo prowadzenia robót konserwatorskich i restauratorskich. Nie bez znaczenia były przemiany własnościowe po 1989 roku, które przyczyniły się do degradacji i zniszczenia wielu obiektów, w tym zwłaszcza pofabrycznych, których utrzymanie okazało się dla miasta ogromnym ciężarem. Rewitalizacja centrum Łodzi stała się niezwykle pilną potrzebą, związaną z koniecznością wprowadzenia odpowiednich regulacji prawnych i pozyskania dużych nakładów finansowych.

W 2010 roku władze miasta podjęły decyzję o wprowadzeniu programu o nazwie „Mia100 Kamienic”, który pozwoliłby na rewitalizację i ochronę choćby części zagrożonych obiektów. Działania te wzorowane były na wrocławskim „Programie 100 Kamienic” zapoczątkowanym wiosną 2007 roku. W ciągu 4 lat przy wsparciu funduszy unijnych wyremontowano we Wrocławiu niemal 150 budynków gminnych. Od 2012 roku zabytkowe obiekty zaczęto odnawiać w ramach „Programu Rewitalizacji Wrocławskich Kamienic”, do którego Zarząd Zasobu Komunalnego kwalifikuje budynki o dużych walorach architektonicznych, zlokalizowane w kluczowych punktach miasta, dbając o odpowiednie wykorzystanie ich potencjału. Dotychczas programem objęto 300 budynków należących do gminy i około 100 kamienic będących własnością wspólnoty. $\mathrm{Na}$ 
remonty w poszczególnych obiektach przeznaczono od 1,5 $\mathrm{mln}$ do $4 \mathrm{mln}$ złotych. W zakres prac wchodzą remonty więźby dachowej i pokrycia dachu, elewacji, klatek schodowych, wykonanie izolacji, likwidacja wspólnych sanitariatów i zrealizowanie ich w obrębie indywidualnych lokali, wymiana instalacji sanitarnych i elektrycznych, a także zmiana systemu ogrzewania [10].

Łódzki program „Mia100 Kamienic” realizowano w latach 2011-2014. Finansowano go ze środków własnych miasta w oparciu o mechanizm polegający na przeznaczaniu określonej puli pieniędzy pochodzących ze sprzedaży i wynajmu nieruchomości komunalnych na jego cel [8 s. 5]. Przyjęty na początku budżet zadania inwestycyjnego wynosił około 236 mln złotych. W 2012 roku na remonty wydano ponad $12 \mathrm{mln}$ złotych, a dwa lata później już ponad $72 \mathrm{mln}$ złotych [5, s. 48]. W 2014 roku nazwę programu zmieniono na „Miasto Kamienic" dając tym samym symboliczny przekaz, iż została przekroczona magiczna liczba stu budynków poddanych rewitalizacji.

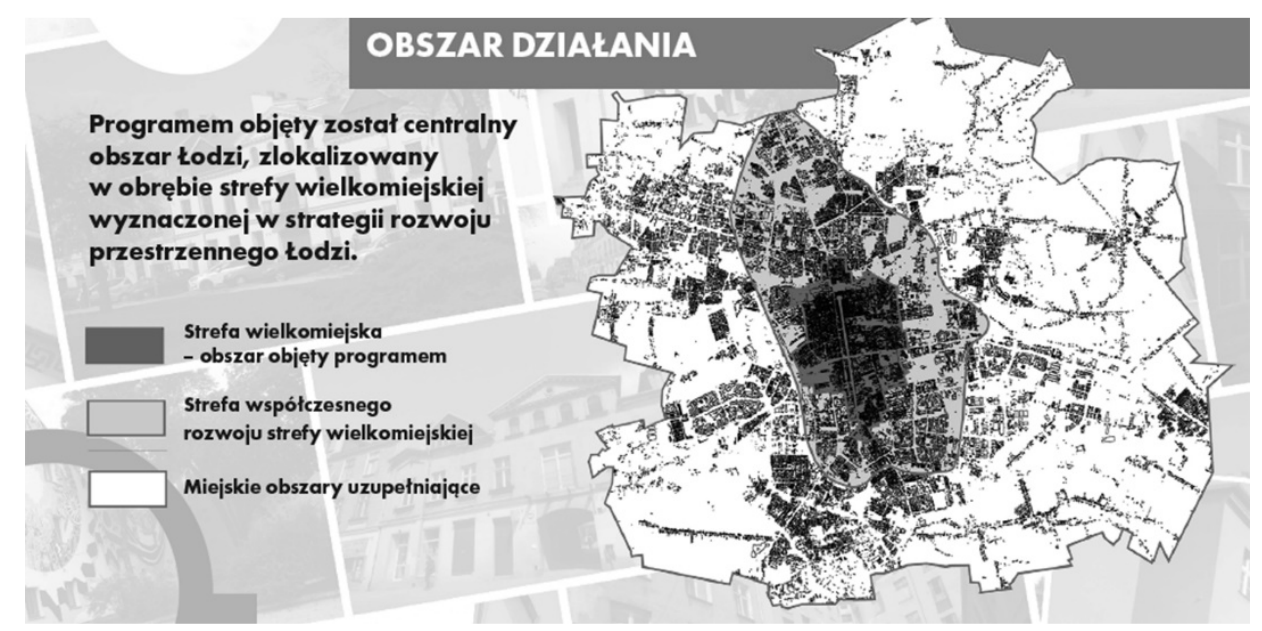

Rys. 1. Obszar oddziaływania programu „Miasto Kamienic”, na podstawie [8]

Fig. 1. The area of the impact of "The City of Tenement Houses" program

Program remontowy obejmuje nieruchomości gminne zlokalizowane w strefie wielkomiejskiej wyznaczonej w strategii rozwoju przestrzennego Łodzi (rys. 1.). Jego głównym celem jest odtworzenie historycznej tkanki architektonicznej z przełomu XIX i XX wieku, którą stanowią nie tylko obiekty mieszkalne, ale także przedszkola, schroniska młodzieżowe, czy też budynki użyteczności publicznej, w większości wpisane do Wojewódzkiego Rejestru Zabytków lub Gminnej Ewidencji Zabytków [8, s. 2]. Towarzyszy mu idea podniesienia atrakcyjności centrum Łodzi, tak by zamieszkanie w tej części miasta było synoni- 
mem prestiżu, a prowadzenie tu działalności gospodarczej było szczególnie opłacalne [5, s. 47]. Podobnie jak w przypadku programów wrocławskich prace remontowo-budowlane obejmują m.in. renowację/ restaurację elewacji, remont prześwitów bramnych, wymianę lub renowację stolarki okiennej i drzwiowej, remont więźby dachowej i poszycia dachowego, klatek schodowych i piwnic, wykonanie izolacji poziomych i pionowych, termomodernizację, osuszanie ścian, wykonanie instalacji centralnego ogrzewania podłączonego do sieci miejskiej, modernizację instalacji wewnętrznych oraz wyposażenie mieszkań w indywidualne łazienki [8, s. 4]. W przeciwieństwie do działań Wrocławia, gdzie podczas trwania remontów mieszkańcy kamienic mogą pozostać w swoich lokalach, w Łodzi prace budowane wiążą się często z wykwaterowaniem. Przed rozpoczęciem remontu mieszkańcy wypełniają ankietę, w której m.in. mogą zadeklarować chęć powrotu do swojego mieszkania. Łączy się to jednak z pewnymi zastrzeżeniami. Jak wspomniano część lokali w kamienicach tzw. strefy wielkomiejskiej zajmują łodzianie o niskich dochodach, których mieszkania są zaniedbane i zadłużone. Władze miasta w przypadku takich osób zapewniają lokale socjalne poza Śródmieściem. Powrót do wyremontowanej kamienicy niesie za sobą podwyżkę opłat (ok. 30\%) z uwagi na podniesienie standardu warunków życia, co również ma decydujący wpływ na „dobór” przyszłych lokatorów. Opuszczone podczas trwania remontu kamienice pozwalają na przeprowadzenie kompleksowych robót budowlanych. Stropy są wymieniane lub wzmacniane, a mieszkania zyskują nowy układ funkcjonalny. W przypadku, gdy niestety nie jest możliwe by nowe ściany działowe uwzględniały dekoracje sztukatorskie (w mieszkaniach w amfiladzie), projektuje się sufit podwieszany, by nie niszczyć zastanej, oryginalnej tkanki i umożliwić jej odsłonięcie w przyszłości. Zdarza się, że miasto przebudowuje lokal według wskazówek konkretnej rodziny, która zdecyduje się wrócić po przeprowadzonych pracach rewitalizacyjnych, tak by spełniało jej potrzeby. Ewentualne zmiany (np. przeprojektowanie łazienki) w wyremontowanych obiektach są możliwe dopiero po upływie gwarancji firmy wykonawczej i pod warunkiem dokonania niezbędnych ustaleń z Zarządem Lokali Miejskich.

Program „Mia100 Kamienic” rozszerzono o prace prowadzone na podwórzach typu naprawa lub wymiana nawierzchni i ogrodzeń, zaprojektowanie miejsc służących rekreacji i wypoczynkowi oraz zagospodarowanie stanowisk służących składowaniu odpadów. Likwiduje się budynki i ogrodzenia zakwalifikowane do rozbiórki, a także kładzie się nacisk na estetyzację instalacji i reklam. $[8$, s. 4].

Ciekawym elementem programu jest włączenie środowiska artystycznego do tworzenia nowego wizerunku miasta. Łódź ozdabia coraz więcej murali malowanych na ścianach szczytowych odnowionych kamienic m.in. przy zbiegu ulicy Więckowskiego i Zachodniej autorstwa rosyjskiego artysty Morika, czy przy ulicy Tuwima 16 autorstwa Mariusza Warasa (rys. 2.). Podwórko jednej z najstarszych budowli objętych programem „Mia100 Kamienic”, dawnego 
Hôtel de Pologne przy ulicy Piotrkowskiej 3, zyskało nową jakość poprzez przekształcenie go w Pasaż Róży według projektu Joanny Rajkowskiej. Elewacje obłożono kawałkami lustra, przez co powstała niezwykła kompozycja odbijająca pokawałkowany na części świat (rys. 3.). Artystka chciała odwołać się do własnych przeżyć związanych z chorobą nowotworową córki Róży i, jak sama mówi, chciała ,żeby budynki zaczęły nas widzieć” [7, s. 65]. Pod koniec 2017 roku w podwórku przy ulicy Więckowskiego 4 ma powstać dzieło kolejnego artysty, tym razem cenionego na całym świecie Wojciecha Siudmaka.

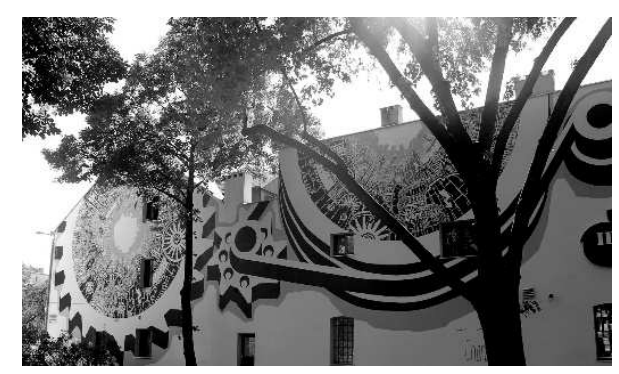

Rys. 2. Mural na ścianie szczytowej kamienicy przy ul. Tuwima 16

Fig. 2. Mural on gable wall of tenement house, Tuwima Street 16,

na podstawie: http://baedekerlodz.blogspot.com (dostęp: 30.05.2017)

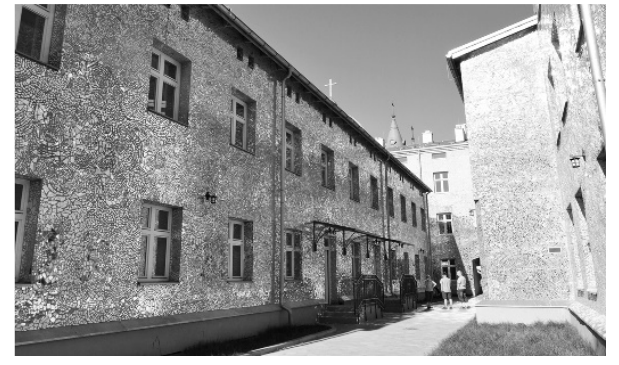

Rys. 3. Pasaż Róży, ul. Piotrkowska 3

Fig. 3. Passage of Rose, Piotrkowska Street 3 na podstawie: http://irdainaction.pl (dostęp: 30.05.2017)

„Miasto Kamienic” związane jest także z programami towarzyszącymi jak „Mieszkania dla młodych”, czy „,Łódzki Strych”. W przypadku pierwszego z nich studenci i absolwenci łódzkich szkół wyższych, którzy otrzymają rekomendację rektora swojej uczelni i są zatrudnieni, mogą ubiegać się o wynajęcie mieszkania w jednej z wyremontowanych kamienic [9]. Projekt „Strych”, zdaniem Architekta Miasta, z założenia adresowany jest do osób odważnych, z wyobraźnią, nieszablonowych, które chciałyby zamieszkać w wyjątkowych wnętrzach w centrum Łodzi. Budynki, w których poddasza i strychy przeznaczono na mieszkania wymagają remontu i adaptacji, ale koszty te można odliczyć w czynszu. Miasto zapewnia doprowadzenie do nich instalacji wodnej i kanalizacyjnej, niekiedy także gazowej [1]. O tym jak dużą popularnością cieszą się lokale na najwyższych kondygnacjach świadczy fakt, że projekt „Mieszkanie na strychu mieszkaniem dla tych, którzy nie boją się wyzwań" miał w 2016 roku już swoją piątą edycję.

Program „Miasto Kamienic” to nie tylko polepszenie warunków bytowych mieszkańców oraz ogólna poprawa wizerunku Łodzi i zachowanie dziedzictwa kulturowego. Wiąże się on także ze zmniejszeniem emisji $\mathrm{CO}_{2}$ do atmosfery poprzez likwidację pieców węglowych, podłączenie do sieci ciepłowniczej 
i termomodernizację, a co za tym idzie z obniżeniem kosztów zużycia energii [8, s. 6-7]. Ponadto w nieruchomościach objętych programem likwiduje się mieszkania socjalne, co umożliwia podniesienie prestiżu budynku, a nawet samej ulicy, przy której jest on usytuowany.

Pozostaje zatem pytanie jak dużą popularnością cieszą się lokale w zrewitalizowanych budynkach? Zmodernizowane i wyposażone w media mieszkania z reguły zajmowane są przez osoby, których kamienica została wytypowana do remontu, o ile mogą pozwolić sobie na zapłatę wyższego niż dotychczas czynszu. Dzięki takiemu zabiegowi pozostają w obrębie strefy wielkomiejskiej i zamieszkują odnowione lokum. Osoby te zazwyczaj rezygnują później z powrotu do swojej pierwotnej kamienicy, ponieważ chcą uniknąć trudów związanych z podwójną przeprowadzką. Partery wyremontowanych budynków przeznacza się na lokale usługowe, choć w pierwszym okresie trwania programu nie zawsze o to zadbano. Obecnie jedynie w oficynach pozostawia się mieszkania dedykując je np. osobom niepełnosprawnym. Zdarza się, że podczas prac budowlanych odkrywane są np. bogate dekoracje sztukatorskie i polichromie. Wówczas budynek dedykuje się w całości na cele usługowe, przy założeniu, że wynajmie go jedna firma lub wprowadza do niego funkcję urzędniczą, tak by jego walory mogli oglądać także interesanci. Taka sytuacja miała miejsce w przypadku kamienicy przy ulicy Piotrkowskiej 171, gdzie obecnie mieści się m.in. siedziba Biura do spraw Rewitalizacji (rys. 4-5).

Przeprowadzane przez miasto remonty mają jeszcze jedną wartość: stają się inspiracją dla wspólnot mieszkaniowych, które także zaczynają inwestować w swoje obiekty (np. przy Placu Komuny Paryskiej 1). Wrocławski samorząd poszedł nawet krok dalej niż Łódź i wspóffinansuje remonty nieruchomości wspólnotowych starając się $\mathrm{w}$ ten sposób mobilizować ich mieszkańców do podejmowania działań [5, s. 45].

Do czerwca 2017 roku zrewitalizowano około 200 łódzkich obiektów w ramach programu „Miasto Kamienic”. Wśród nich znajduje się mnóstwo „perełek architektonicznych", którymi miasto może się szczycić. Należy do nich m.in. najstarszy w Łodzi murowany dom piętrowy zlokalizowany przy ulicy Piotrkowskiej 243, stanowiący znakomity przykład architektury neorenesansowej. Obiekt powstał w 1834 roku dla tkacza Gottlieba Beera. W 1899 roku został poddany rozbudowie według projektu znanego łódzkiego architekta Edwarda Cretzburga. W trakcie prac rewitalizacyjnych w latach 2013-2014 odnowiono elewacje, odtworzono balkon w elewacji frontowej, wymieniono część stolarki okiennej i drzwiowej, wprowadzono nowy układ funkcjonalny dostosowując budynek do obowiązujących przepisów, norm i wymogów stawianych pomieszczeniom mieszkalnym i użyteczności publicznej, odtworzono oryginalny prześwit bramowy, wymieniono konstrukcję dachową i stropy międzykondygnacyjne, odtworzono oficynę północną, wykonano nowe instalacje oraz przebudowa- 
no podwórze ${ }^{2}$. Realizowane prace wzbudziły zainteresowanie łodzian, którzy chętnie (i przychylnie) komentowali postępy na forach internetowych (rys. 6-7).

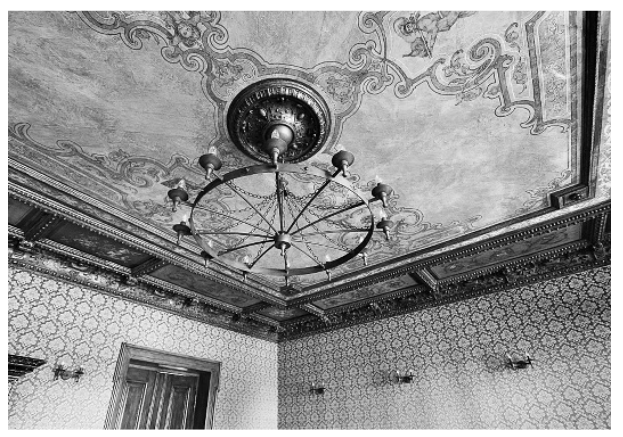

Rys. 4. Wnętrze kamienicy przy ul. Piotrkowskiej 171

Fig. 4. Interior of a tenement house, Piotrkowska Street 171

na podstawie: http://cachfoto.blogspot.com/ 2013/ 08/ piotrkowska-171173-kamienicaadolfa.html (dostęp: 30.05.2017)

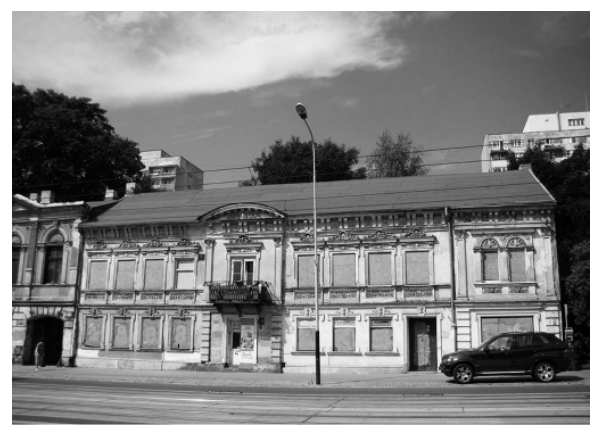

Rys. 6. Kamienica Beera przy ul. Piotrkowskiej 243 przed remontem

Fig. 6. Beer's tenement house, Piotrkowska Street 243 before renovation

na podstawie: fotoreporter24.pl/2012/07/

15/moje-miasto-ulica-piotrkow-

ska/dsc03610_2/ (dostęp: 30.05.2017)

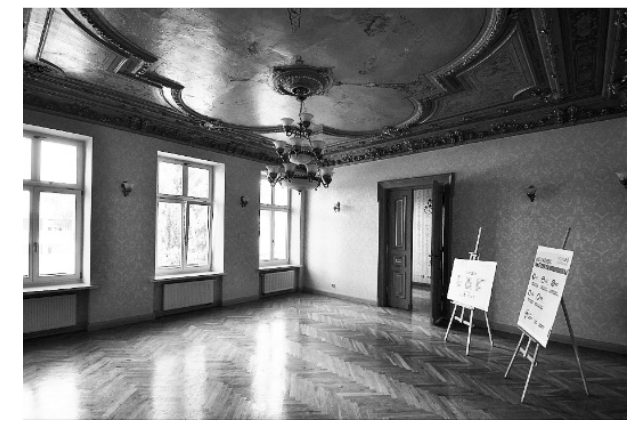

Rys. 5. Wnętrze kamienicy przy ul. Piotrkowskiej 171

Fig. 5. Interior of a tenement house, Piotrkowska Street 171

na podstawie: http://coachfoto.blogspot.com/ 2013/08/ piotrkowska-171173-kamienicaadolfa.html (dostęp: 30.05.2017)

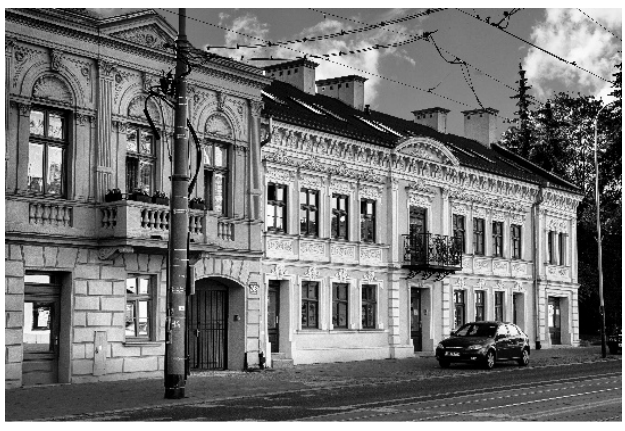

Rys. 7. Kamienica Beera przy ul. Piotrkowskiej 243 po remoncie

Fig. 7. Beer's tenement house, Piotrkowska Street 243 after renovation

źródło/source: fot. autorki/ own photo

Jednym z pierwszych budynków objętych programem „Mia100 Kamienic” jest narożna kamienica przy ulicy Legionów 2/ plac Wolności 4 (rys. 7-8).

${ }^{2}$ Dane uzyskane z archiwum Urzędu Miasta Łodzi 
Wzniesiono ja prawdopodobnie pod koniec lat 30. XIX wieku dla Jana Reutera. Od początku w pomieszczeniach na parterze lokalizowano cukiernię. W 1857 roku Otto Szwetysz otworzył tam „Cukiernię Warszawską” odwiedzaną przez najznamienitszych mieszkańców Łodzi. W 1886 roku lokal przejął Zdzisław Konrad, który go rozbudował i urządził na wzór kawiarni wiedeńskich. Przez lata organizował koncerty, zabawy taneczne i pokazy teatru żywych fotografii. Jeszcze po II wojnie światowej w parterze istniała funkcja gastronomiczna. W latach 1951-1952 kamienicę nadbudowano o jedną kondygnację. Obecnie mieszczą się w niej lokale usługowe, restauracja oraz mieszkania. Podczas prac rewitalizacyjnych odnowiono elewacje wraz z odtworzeniem oryginalnej kolorystyki, dokonano remontu podcieni, prześwitu bramowego, klatki schodowej i części piwnic budynku ${ }^{3}$. Dziś widok kamienicy cieszy łodzian i nie kontrastuje przykro swoim zaniedbanym wyglądem z ultranowoczesnym, całkowicie przeszklonym obiektem na działce obok.

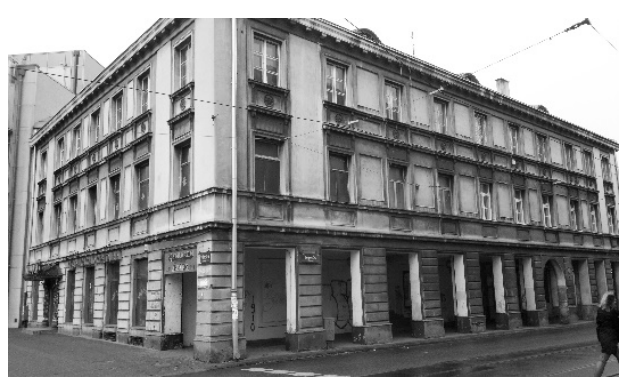

Rys. 8. Kamienica przy ul. Legionów 2 przed remontem

Fig. 8. Tenement house, Legionów Street 2 before renovation

źródło/source: fot. autorki/ own photo

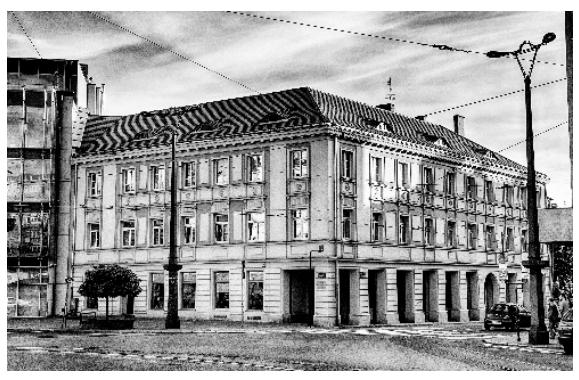

Rys. 9. Kamienica przy ul. Legionów 2 po remoncie

Fig. 9. Tenement house, Legionów Street 2 after renovation

źródło/source: fot. autorki/ own photo

Jak wspomniano, program „Miasto Kamienic” obejmuje także przedszkola, szkoły, czy też schroniska młodzieżowe. W 2014 roku wyremontowano m.in. budynek o manierystycznych dekoracjach mieszczący Przedszkole Miejskie $\mathrm{Nr}$ 75 przy al. Kościuszki 81, pochodzący z 1895 roku (rys. 9-10). Część detali sztukatorskich w partiach przyziemia uległa wcześniej zniszczeniu lub deformacji. W obiekcie zachowała się kompletna, oryginalna stolarka okienna wyposażona w żaluzje, która posłużyła za wzorzec do jej odtworzenia. Prace rewitalizacyjne obejmowały remont elewacji, wymianę stolarki okiennej, bramy wjazdowej, krat okiennych, a także wykonanie izolacji przeciwwilgociowej piwnic i remont przejazdu bramowego ${ }^{4}$. Napawa optymizmem fakt, że dzieci mogły

\footnotetext{
${ }^{3}$ Tamże

${ }^{4}$ Tamże
} 
zaobserwować jak pozytywnie zmieniło się ,ich” przedszkole i należy mieć nadzieję, że przeprowadzona rewitalizacja korzystnie wpłynęła na zasianie w nich ziarenka szacunku do zabytków.

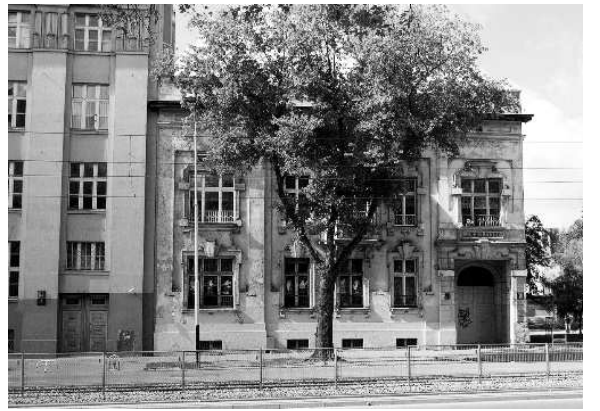

Rys. 10. Kamienica przy al. Kościuszki 81 przed remontem; na podstawie: fotopolska.eu/foto/459/459182.jpg (dostęp: 30.05 . 2017)

Fig. 10. Tenement house, Kościuszki Avenue 81 before renovation

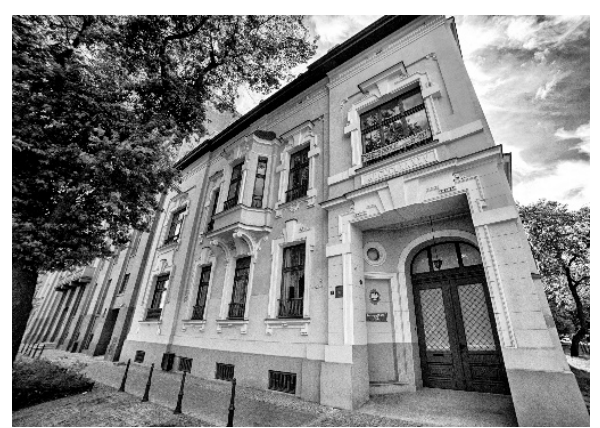

Rys. 11. Kamienica przy al. Kościuszki 81 po remoncie; źródło: fot. autorki

Fig. 11. Tenement house, Kościuszki Avenue 81 after renovation; source: own photo

Można by przywoływać jeszcze bardzo wiele przykładów remontów, które odbyły się na przestrzeni ostatnich sześciu lat w Łodzi. Odnowione fasady cieszą oczy i podnoszą morale mieszkańców. Zapraszając gości z innego miasta $z$ dumą pokazujemy piękno eklektycznych kamienic. Naturalnie zdarzają się wśród nich przypadki krytykowane za zbyt ogólne podejście do rewitalizacji, czy wręcz ,przypudrowanie elewacji frontowej”. Niekiedy łodzianom brakuje cierpliwości by poczekać na efekt końcowy i salwy krytyki rozbrzmiewają nim prace zostaną zakończone. Na pewno kwestią budzącą kontrowersje pozostaje wybór firmy wykonawczej podczas przetargu, gdzie cena jest wciąż głównym wyznacznikiem. Rodzi to niezdrową konkurencję na rynku i niestety często jedynymi „ofiarami” takiego stanu rzeczy stają się zabytki. Faktem jest jednak, że proceder ten ma miejsce nie tylko w Łodzi, ale w całym kraju i, w imię szacunku dla dziedzictwa architektonicznego, które mamy przekazać przyszłym pokoleniom, powinien jak najszybciej zostać odgórnie, prawnie uregulowany.

Czy w ogólnym rozrachunku program „Miasto Kamienic” przyczynił się do poprawy odbioru wizualnego Łodzi? Zdecydowanie tak. Ma także wartość niemierzalną: uświadomił wielu osobom w jak unikatowym pod kątem architektonicznym mieście żyją. Czekamy z niecierpliwością na ciąg dalszy. Już pod koniec tego roku ma rozpocząć się „Rewitalizacja obszarowa”, której będą podda- 
ne całe kwartały. Mamy nadzieję, że za kilka lat nikt już nie będzie pamiętać określenia: „kochana, szara Łódź z dymiącymi kominami”.

Bardzo dziękuje za okazana pomoc przy przygotowaniu artykułu Pani Inspektor Agnieszce Stachowicz - Kassyańskiej z Biura ds. Rewitalizacji w Łodzi i Pani Rzecznik Prasowej Urszuli Hamkato z ZZK Wroctaw

\section{Literatura}

[1] Baranowska J.:, UMŁ wynajmuje mieszkania na poddaszach. „Łódzki strych” nowy projekt władz Łodzi, Polska Dziennik Łódzki, 27.05.2017, http://lodz.naszemiasto.pl/artykul/uml-wynajmuje-mieszkania-na-poddaszach-lodzki-strychnowy,1872488, artgal,t,id,tm.html (dostęp: 30.05.2017)

[2] Jaworowski H.: Łódź, w: Kalinowski W. (red.), Tom 1. Miasta historyczne, w: Zin W. (red.), Zabytki urbanistyki i architektury w Polsce. Odbudowa i konserwacja, Wydawnictwo Arkady, Warszawa 1986

[3] Kaszuba K.: Łódź. Miasto czterech kultur, Wydawnictwo Takon, Łódź 2001

[4] Lipecka - Kobojek G., Bonisławski R.: Zachowaj Łódź w sercu, Wydawn. Sagalara, Łódź 2002

[5] Romanowski G.: Mia100 Kamienic. Przywracanie normalności, Kronika Miasta Łodzi nr 4, 2015

[6] Salm J.: Łódzka nostalgia, w: Kaszuba K. (red.), Łódź. Miasto czterech kultur, Wydawn. Takon, Łódź 2001

[7] Stefański K.: Mia100 Kamienic - realizacja programu na wybranych przykładach, Renowacje i Zabytki nr I (57), 2016

[8] Miasto Kamienic. Rewitalizacja obszarowa centrum Łodzi, folder informacyjny Urzędu Miasta Łodzi

[9] http://www.uml.lodz.pl/miasto/aktualnosci/?news=23180 (dostęp: 30.05.2017)

[10]http://www.zzk.wroc.pl/index.php/remonty/program-rewitalizacji-wrocawskichkamienic (dostęp: 30.05.2017)

\section{REVITALIZATION OF THE ARCHITECTURAL HERITAGE OF LODZ IN THE FRAMEWORK OF "THE CITY OF 100 TENEMENT HOUSES" PROGRAM}

\section{S u m m a r y}

The aim of the article is to discuss the assumptions of renovation program implemented from 2011 for municipal property located in the urban zone of Lodz. Among the buildings included by the project "The City of 100 Tenement Houses" are residential and public buildings, kindergartens, youth hostels, as well as art galleries, entered in the Regional Register of Monuments and the Municipal Records of Historical Monuments. The author draws attention to the aspect of the reconstruction of the historical urban tissue from the turn of the $19^{\text {th }}$ and the $20^{\text {th }}$ century within the framework of the program, as well as on the social role of implemented revitalization works and attempts to answer the question whether this type of activity is a remedy on animating emptying 
center of the city. Selected residential and public buildings from the turn of the $19^{\text {th }}$ and $20^{\text {th }}$ centuries were benchmarked, in which thorough renovations and revitalization works were led. In addition to the restoration - building initiatives, the author shows a spectrum of tasks which accompany the program "The City of 100 Tenement Houses" with socio-sociological background. On top of that, she confronts executed works with accomplishments of revitalization of Wroclaw, where the prototype of the Lodz repair program was led. Considerations led to the conclusion that completed renovations besides to enhancing the visual value of the city met with a positive social reception. The program contributes to the gradual occupation of restored buildings and in opinion of residents, Lodz is no longer a synonym for grey city, unwilling to change. It starts the era of the city conscious of its heritage, architectural wealth, as well as its dormant potential.

Keywords: repair program, tenement house, restoration, monument, urban zone

Przestano do redakcji: 09.06.2017 r.

Przyjęto do druku: 01.09.2017 r. 